\title{
Pendampingan Inovasi Produk dan Pemasaran pada Kelompok Usaha Kue Ladrang Di Desa Karangsono Kecamatan Bangsalsari Kabupaten Jember
}

\author{
Khoirul Ifa \\ STIE Widya Gama Lumajang \\ khoirul_ifa@yahoo.co.id
}

\begin{abstract}
ABSTRAK
Kegiatan ini bertujuan untuk mengembangkan inovasi produk dan pemasaran pada kelompok usaha kue ladrang di desa karangsono kecamatan bangsalsari kabupaten jember sehingga produk tersebut memiliki daya saing yang tinggi. Adapun metode kegiatan pengabdian masyarakat mempunyai beberapa tahapan yaitu (1) Survey : Kegiatan survey akan dilaksanakan guna melihat kondisi usaha mitra, (2) Wawancara : Pelaksanaan wawancara bertujuan untuk menggali informasi terkait permasalahan-permasalahan mitra dan sekaligus menemukan solusinya, (3) Praktek inovasi kemasan dan varians rasa produk : Praktek inovasi kemasan dibantu oleh dosen dengan mendisign kemasan yang lebih menarik dan unik, sedangkan varians rasa produk didampingi oleh dosen, (4) Monitoring dan evaluasi : Kegiatan monitoring dan evaluasi akan dilaksanakan secara periodik sampai mitra dapat menghasilkan produk-produk yang inovatif sehingga target dan luaran program ini bisa tercapai. Target Kegiatan program Pengabdian Masyarakat kelompok usaha kue ladrang ini di Desa Karangsono Kabupaten Jember adalah : (1) Perluasan pasar, tidak hanya pemasaran di warung-warung desa setempat tetapi di daerah terdekat seperti Lumajang. (2) Peningkatan kualitas produk baik inovasi rasa maupun kemasan.
\end{abstract}

Kata Kunci : Kue Ladrang; Inovasi Kemasan; Inovasi Rasa: Pemasaran

ABSTRACT

This activity aims to develop product and marketing innovation in ladrang pastry business group in karangsono village sub district bangsalsari jember district so that the product has high competitiveness. The method of community service activity has several stages: (1) Survey: The survey activity will be conducted to see the business condition of the partner, (2) Interview: The purpose of the interview is to explore information related to the problems of the partner and also to find the solution, (3) packaging and product taste variance: The packaging innovation practice is assisted by lecturers by designing more attractive and unique packaging, while the taste variances are accompanied by lecturers, (4) Monitoring and evaluation: Monitoring and evaluation activities will be conducted periodically until partners can produce innovative products so that the target and outcome of this program can be achieved. The Target of Community Service Activities of this cake ladrang business group in Karangsono Village, Jember Regency are: (1) Market expansion, not only marketing in local village stalls but in nearby areas such as Lumajang. (2) Improvement of product quality both taste and packaging innovation.

Keywords: Ladrang Cake; Packaging Innovation; Innovation Sense: Marketing

\section{PENDAHULUAN}

\section{A. Analisis Situasi Mitra Pengabdian}

Penguatan usaha merupakan salah satu alternatif untuk menjadikan masyarakat lebih mandiri. Pengusaha khususnya UMKM dituntut untuk lebih kreatif dan inovatif dalam mencipatakan 
aneka produk yang dapat bersaing pada taraf lokal maupun nasional. Ada beberapa cara yang dapat ditempuh untuk menghasilkan produk yang inovatif (Kotler, 1987 dalam Kusumo, 2006), yaitu dengan cara mengembangkan atribut produk baru, mengembangkan beragam tingkat mutu dan mengembangkan model dan ukuran produk. Inovasi produk sangat di butuhkan untuk meningkatkan mutu dan hasil penjualan. Namun UMKM juga tidak luput dari berbagai permasalahan, Hadiyati (2010) menyatakan survey dari BPS mengidentifikasi permasalahan UMKM berdasarkan prioritasnya, yaitu meliputi : (1) kurangnya permodalan, (2) kesulitan dalam pemasaran, (3) persaingan usaha yang ketat, (4) kesulitan bahan baku, (5) kurang teknis produksi dan keahlian, (6) kurangnya keterampilan manajerial (SDM), (7) kurangnya pengetahuan masalah manajemen khususnya bidang keuangan dan akuntansi.

Permasalahan yang lain UMKM juga kesulitan dalam pemasaran sehingga membutuhkan promosi ekstra untuk meningkatkan hasil penjualannya. Di dalam era digital seperti sekarang ini, peran media sosial sangat penting untuk menunjang promosi produk UMKM. Beberapa permasalahan UMKM tersebut sepatutnya di jadikan motivasi para pengusaha khususnya home industry untuk meningkatkan mutu produknya sehingga menghasilkan produk yang inovatif dan kreatif.

Usaha yang paling banyak di minati khususnya untuk kalangan home industry adalah usaha makanan dan minuman, di samping proses pengolahannya mudah, bisnis makanan tidak membutuhkan modal yang besar. Salah satu usaha makanan di Indonesia yaitu usaha makanan ringan.

Bisnis makanan ringan merupakan bisnis berskala rumah tangga yang memiliki peluang sangat bagus untuk saat ini maupun yang akan datang. Permintaan pasar untuk makanan ringan terus mengalir. Melihat penikmat makanan ringan, tidak hanya anak-anak, tetapi juga remaja, dewasa, hingga orang tua. Maka tidak mengherankan jika pelaku bisnis makanan yang sering disajikan sebagai selingan saat melakukan kegiatan ini sering kali kebanjiran pelanggan (Dera, 2016). Jenis makanan ringan ini dapat berupa gorengan, kerupuk, jajanan pasar, dan aneka keripik, kue kering, dan sebagainya.

Kue ladrang adalah nama jenis kue kering yang memiliki tekstur sangat renyah. Kue kering yang satu ini memiliki rasa yang sangat gurih dan nikmat. Selain itu, kue ladrang juga biasanya banyak disajikan ketika sedang bersantai besama keluarga. Kue ladrang dapat juga dikatakan sebagai kue bawang karena proses dan bahan yang digunakan mungkin hampir sama ataupun benar-benar sama hanya saja penamaannya yang berbeda karena tiap derah memang memiliki bahasa yang berbeda namun maksudnya sama. (http://www.resepnasional.com/).

Kegiatan membuat kue ladrang sudah banyak di lakukan di kalangan masyarakat. Di desa karangsono kecamatan bangsalsari sebagian masyarakat ada yang memiliki usaha membuat kue ladrang, usaha tersebut sudah ditekuni sejak awal tahun 2017, namun usaha tersebut memiliki banyak permasalahan disamping produknya yang tidak inovatif dari segi rasa dan kemasan, pemasaran kue ladrang juga masih tradisional, pemasaran masih di warung-warung desa setempat dan belum dipasarkan secara online. 


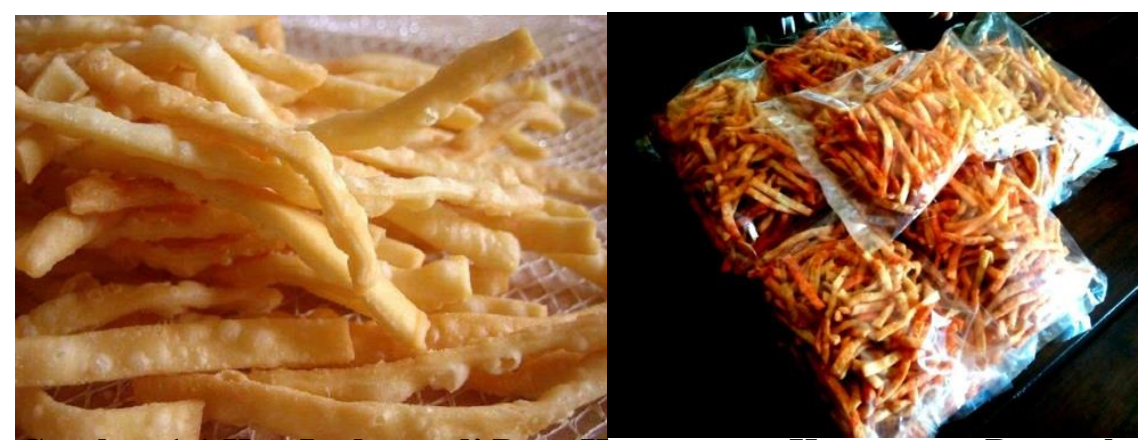

Gambar 1.1 Kue Ladrang di Desa Karangsono Kecamatan Bangsalsari

\section{Kabupaten Jember}

Dari segi rasa kue ladrang di desa karangsono kecamatan bangsalsari masih mempunyai 2 varians rasa, yaitu rasa asin dan rasa balado (pedas) sehingga butuh inovasi rasa yang lebih variatif, disamping itu kemasan masih sederhana menggunakan plastik ukuran kecil, tipis dan belum di beri merk (nama) sehingga perlu di lakukan inovasi kemasan yang higienis dan unik

Dalam hal pemasaran masih di warung-warung desa setempat belum di pasarkan di luar daerah ataupun melalui online, sehingga perlu pendampingan dalam hal pengayaan produk dan pendampingan pemasaran.

\section{B. Permasalahan Mitra}

Dalam perkembangannya pengusaha kue ladrang masih mengalami berbagai permasalahan, di antaranya:

1. Kurangnya permodalan yang dimiliki.

2. Belum ada sentuhan teknologi dalam proses produksinya

3. Belum adanya inovasi produk baik varians produk maupun kemasan produk

4. Terbatasnya akses pemasaran

5. Produk belum di pasarkan secara online.

\section{SOLUSI DAN TARGET LUARAN}

\section{A. Target Kegiatan}

Ukuran keberhasilan program Pengabdian Masyarakat kelompok usaha kue ladrang ini di Desa Karangsono Kabupaten Jember adalah dengan tercapainya target kegiatan ini, adapun target kegiatan ini adalah :

1. Perluasan pasar, tidak hanya pemasaran di warung-warung desa setempat tetapi di daerah terdekat seperti Lumajang.

2. Peningkatan kualitas produk baik inovasi rasa maupun kemasan.

\section{B. Luaran Kegiatan}

Kegiatan Pengabdian Masyarakat ini di harapkan memberikan luaran bagi mitra sebagai berikut : 
1. Perluasan pasar diluar daerah

2. Pendampingan promosi online

3. Inovasi varians rasa yaitu rasa barbeque, sapi panggang dan rasa manis.

4. Inovasi kemasan plastik ukuran besar dan lebih tebal serta pemberian label (merk) dalam kemasan kue ladrang.

\section{METODE PELAKSANAAN}

\section{A. Tahapan dalam melaksanakan solusi permasalahan mitra}

Dari permasalahan diatas maka ada beberapa solusi yang ditawarkan melalui tahapan tahapan sebagai berikut :

1. Tahapan pertama : pelaksanaan survey kepada mitra guna melihat kondisi usaha mitra.

2. Tahapan kedua : pelaksanaan wawancara kepada mitra guna menggali berbagai permasalahanpermasalahan usaha dan menggali berbagai informasi terkait dengan usaha.

3. Tahapan ketiga: mendesign kemasan produk, melaksanakan inovasi dan memperbanyak varians rasa produk.

4. Tahapan keempat : pendampingan pemasaran di daerah terdekat, pendampaingan promosi online.

5. Tahapan kelima : monitoring dan evaluasi.

\section{B. Metode Pendekatan yang ditawarkan}

Metode pendekatan yang ditawarkan untuk menyelesaikan permasalahan mitra terdiri dari langkah-langkah sebagai berikut :

1. Survey

Kegiatan survey akan dilaksanakan guna melihat kondisi usaha mitra.

2. Wawancara

Pelaksanaan wawancara bertujuan untuk menggali informasi terkait permasalahan-permasalahan mitra dan sekaligus menemukan solusinya.

3. Praktek inovasi kemasan dan varians rasa produk

Praktek inovasi kemasan dibantu oleh dosen dengan mendisign kemasan yang lebih menarik dan unik. Sedangkan varians rasa produk didampingi oleh dosen.

4. Monitoring dan evaluasi

Kegiatan monitoring dan evaluasi akan dilaksanakan secara periodik sampai mitra dapat menghasilkan produk-produk yang inovatif sehingga target dan luaran program ini bisa tercapai.

\section{HASIL YANG DI CAPAI}

\section{A. Kegiatan Survey}

Persiapan awal sebelum melakukan wawancara terhadap pelaku usaha kue ladrang di desa karangsono kecamatan bangsalsari kabupaten jember adalah survey, kegiatan survey dilakukan dengan 
tujuan untuk melihat kondisi awal usaha kue ladrang, kegiatan ini juga bertujuan untuk mempersiapkan program pengabdian masyarakat, serta bertujuan untuk mengumpulkan data dan informasi terkait usaha.

Kegiatan survey di lakukan pada tanggal 10 Februari 2018, temuan survey diketahui bahwa usaha ini kurang berkembang di samping karena kurangnya inovasi produk baik varians rasa, dan kemasan usaha ini juga lemah dalam hal pemasaran. Kegiatan survey juga menghasilkan serangkaian susunan program pengabdian masyarakat yang selanjutnya dan tentunya dibahas oleh mitra dan pelaksana program pengabdian msyarakat. Berikut merupakan hasil dokumentasi kegiatan survey pada kelompok usaha kue ladrang di desa karangsono kecamatan bangsalsari kabupaten jember.

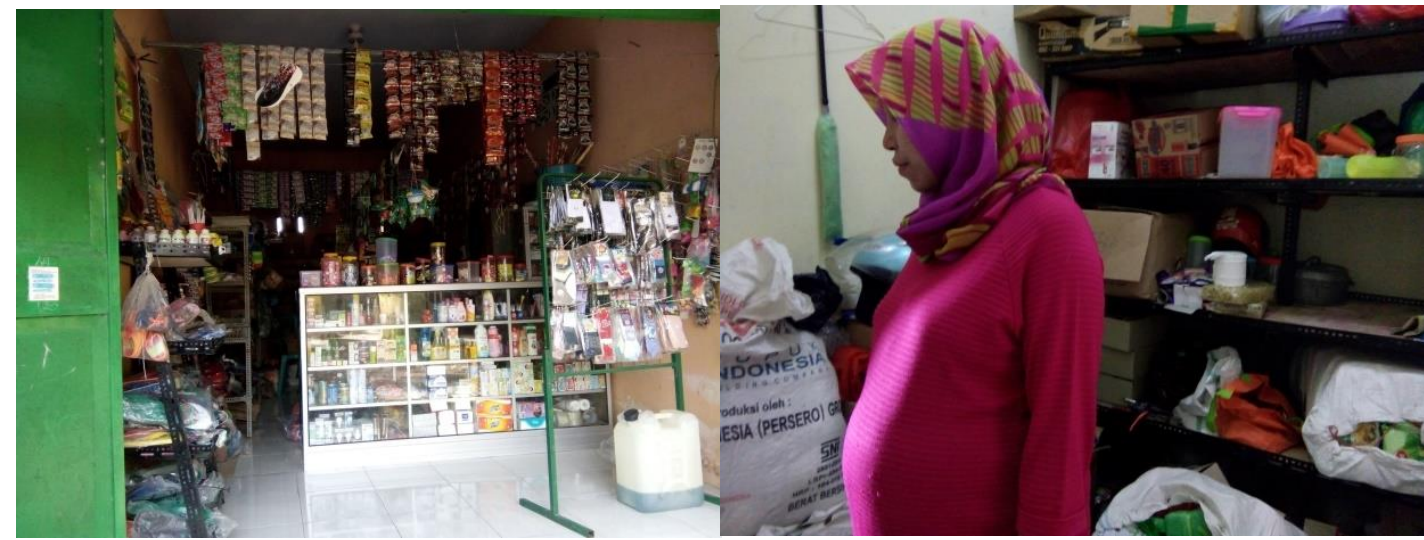

\section{Gambar 5.1 Kegiatan Survey Kelompok Usaha Kue Ladrang di Desa Karangsono Kecamatan Bangsalsari Kabupaten Jember}

\section{B. Kegiatan Wawancara}

Langkah kedua dalam pelaksanaan program pengabdian masyarakat adalah kegiatan wawancara. Wawancara di perlukan untuk menggali informasi terkait usaha kue ladrang, informasi yang digali berupa identitas usaha, modal dan omset, jumlah tenaga kerja, harga jual, bahan-bahan yang digunakan, peralatan yang digunakan, daerah pemasaran, bahan baku, proses pembuatan kue dan hasil produksi.

Kegiatan wawancara dilaksanakan pada tanggal 11 Februari 2018, hasil wawancara menunjukkan usaha kue ladrang memiliki banyak permasalahan, dari segi varians rasa kue ladrang hanya mempunyai 2 varians rasa yaitu original dan balado, sedangkan pengemasan masih sederhana yaitu menggunakan plastik ukuran kecil dan tipis, label kemasan masih belum ada. Pemasaran kue ladrang hanya pada warung-warung terdekat dan pedagang sayur. Kue ladrang ini banyak di gemari oleh masyarakat sekitar disamping karena cita rasanya yang enak, harga kue ladrang juga tergolong murah. Pendampingan terhadap pelaku usaha kue ini sangat diperlukan agar pelaku usaha lebih mandiri. 


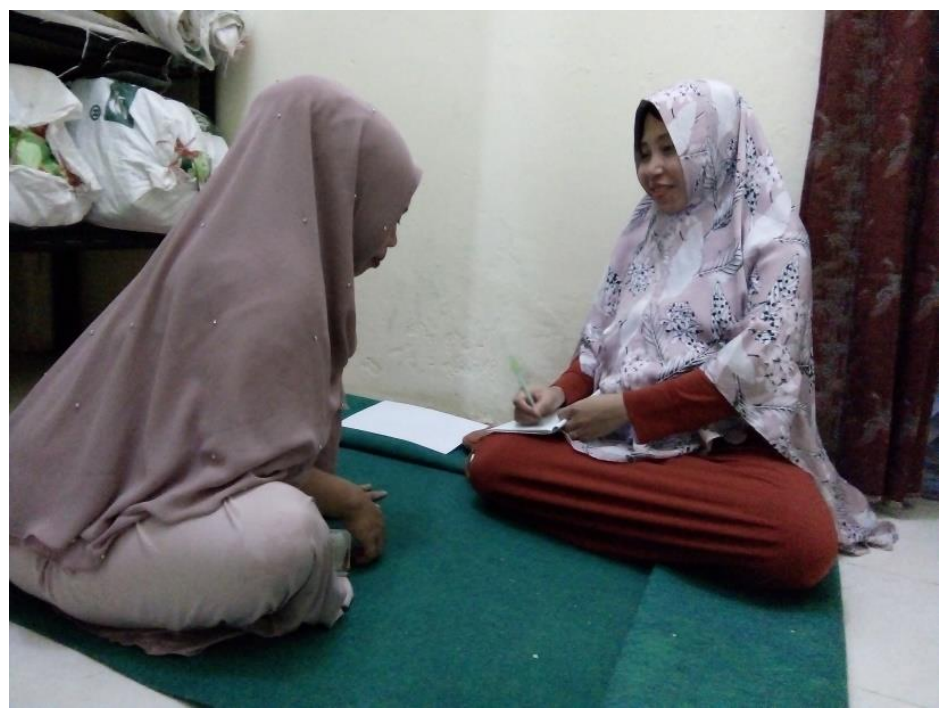

\section{Gambar 5.2 Proses Wawancara Kepada Kelompok Usaha Kue Ladrang Desa Karangsono Kecamatan Bangsalsari Kabupaten Jember}

\section{Identitas Usaha}

Usaha kue ladrang milik ibu yeni ini berdiri sejak tahun 2017, usaha ini merupakan usaha makanan yang digeluti oleh satu keluarga yang terdiri dari ibu, ayah, anak dan saudara-saudaranya.

\section{Modal Dan Omset Usaha}

Modal usaha kue ladrang ini hanya sebesar 150.000 kemudian berkembang seiring dengan banyaknya jumlah pesanan, pesanan terbanyak biasanya menjelang hari raya idul fitri. Omset usahanya tidak banyak hanya sekitar 20.000-50.000 per harinya, namun jika jumlah pesanan meningkat omset usaha inipun semakin meningkat, per hari mencapai 100.000-200.000.

\section{Jumlah Tenaga Kerja}

Jumlah tenaga kerja hanya 4 orang yang terdiri dari sanak keluarga. Basis usaha ini yaitu home industry.

\section{Harga Jual Per Unit}

Harga jual per unit kue ladrang yaitu Rp 1.000 karena mereka hanya mengemas dalam plastik kecil yang kemudian disetorkan pada warung-warung, pasar dan pedagang sayur.

\section{Bahan-Bahan Yang Digunakan}

Adapun bahan-bahan yang digunakan antara lain :

- Tepung terigu

- Tepung kanji

- Bawang putih

- Garam

- Penyedap makanan

- Mentega

- Daun jeruk 


\section{Peralatan Yang Digunakan}

- Mesin pencetak mie

- Gunting

- Mesin pengemasan

\section{Daerah Pemasaran}

Daerah pemasaran yaitu daerah lokal jember yaitu daerah sekitar kecamatan bangsalsari yang terdiri dari pasar-pasar tradisional, warung-warung terdekat dan pedagang sayur.

\section{Bahan Baku}

Bahan baku pembuatan kue ladrang ini adalah tepung terigu yang dapat di beli pada toko terdekat. Satu kilogram tepung terigu kualitas baik seharga Rp 10.000.

Bahan baku kue ladrang dapat dibeli di toko-toko kue maupun toko peracangan, sedangkan bahan pelengkap lainnya juga banyak dijumpai di toko peracanagan maupun pasar terdekat, sehingga bahan baku tergolong mudah di dapat.

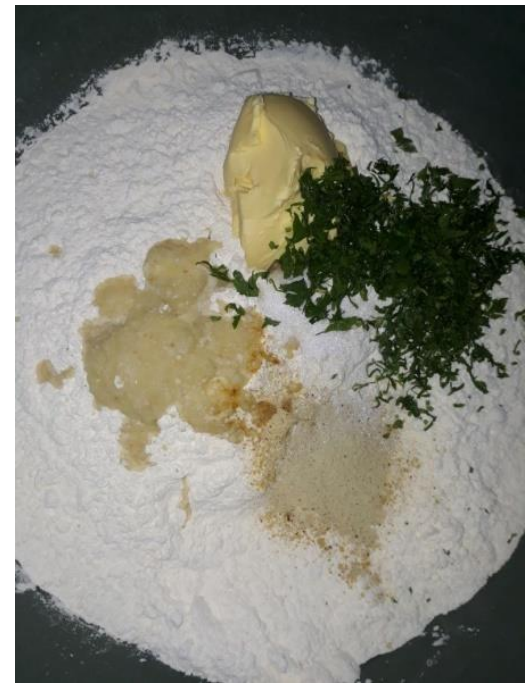

Gambar 5.3 Bahan Baku Kue Ladrang

\section{Proses Pembuatan Kue Ladrang}

Adapun proses pembuatan kue ladrang tidaklah sulit, langkah pertama campurkan bahanbahan seperti tepung, garam, penyedap, mentega, bawang putih yang sudah dihaluskan, dan daun jeruk yang sudah dipotong kecil kemudian tambahkan sedikit air dan di aduk mengunakan tangan. Adonan yang dibuat juga tidak terlalu encer dan tidak pula terlalu keras, setelah adonan menyatu dicetak dalam cetakan penipis adonan hingga membentuk adonan yang tipis, langkah selanjutkan adonan di masukkan lagi pada mesin cetak mie untuk membentuk kue ladrang dalam bentuk panjang, setalah itu gunting sesuai ukuran. Setelah di gunting kemudian siapkan wajan berisi minyak panas, kemudian goreng hingga kecoklatan, kemudian tiriskan dan siap untuk dicampur dengan aneka rasa, seperti balado dan asin. Untuk perasa pemilik kue ladrang menggunakan perasa siap saji yang dijual dipasaran. 


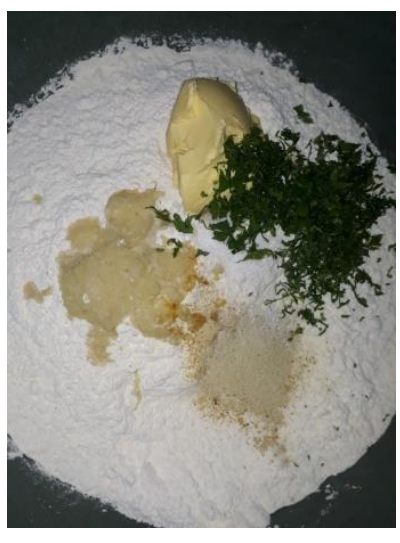

Langkah 1 :

Campurkan bahanbahan

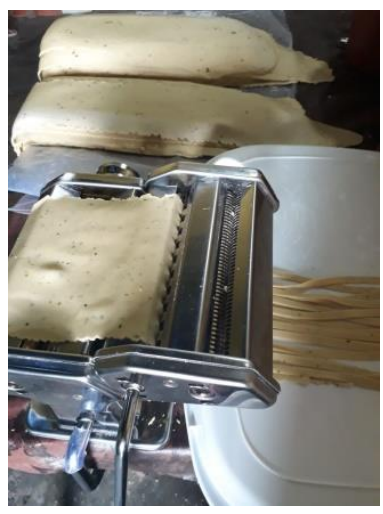

Langkah 5 : Setelah terbentuk tipis masukkan ke mesin siller

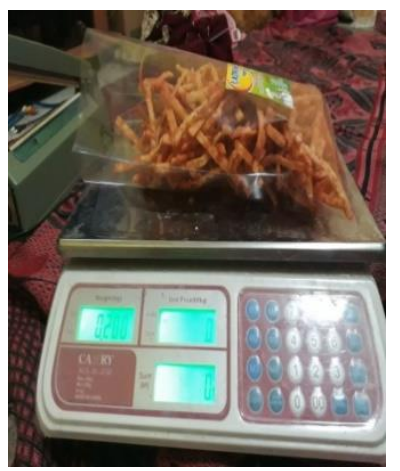

Langkah 8 : Timbang sesuai ukuran

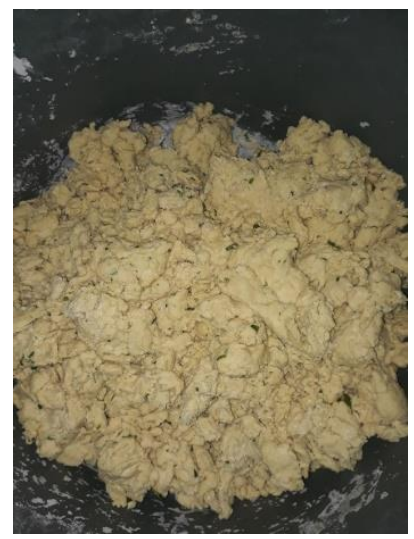

Langkah 2 : Aduk semua bahan sampai membentuk adonan

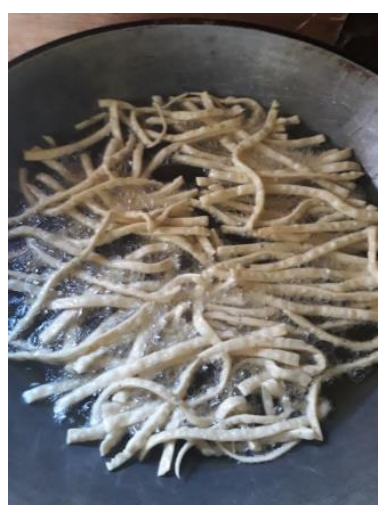

Langkah 6 : Goreng adonan yang telah dipotong-potong

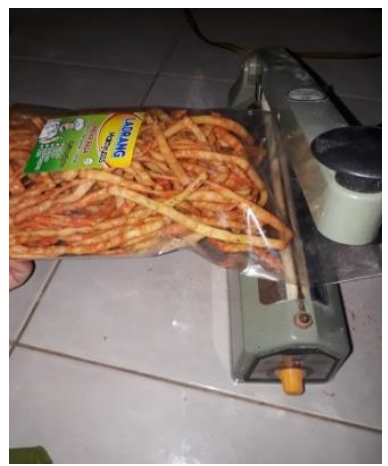

Langkah 9 : Proses pengepresan

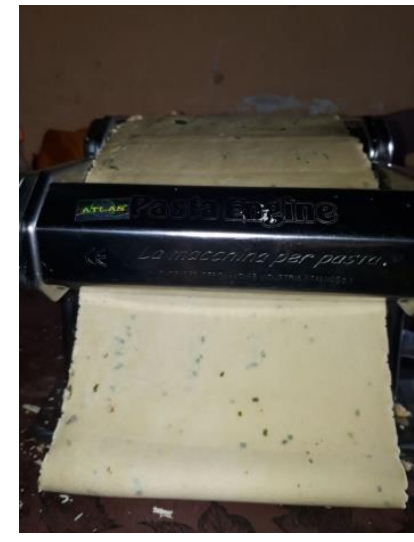

Langkah 3 : Adonan di masukkan mesin siller (penipis adonan)

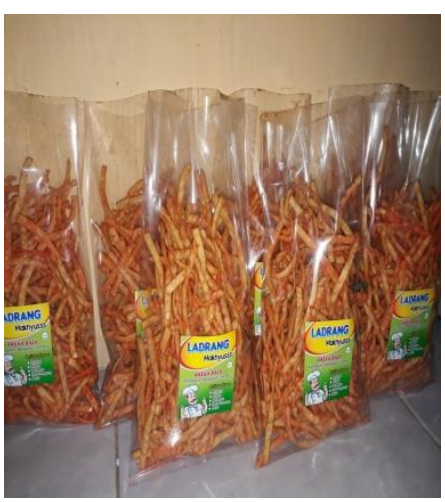

Langkah 7 : Kemas

kue ladrang sesuai ukuran plastik 
Gambar 5.4 Proses Pembuatan Kue Ladrang Di Desa Karangsono Kecamatan Bangsalsari Kabupaten Jember

\section{Praktek Desaign, Inovasi dan Varians Produk}

Praktek desaign, inovasi dan varians produk telah dilaksanakan pada tanggal 13 Februari 2018, sekelompok pengusaha antusias dalam pemberian arahan arahan dari tim pelaksana pengabdian masyarakat, dengan kecanggihan teknologi internet dosen mendampingi para kelompok usaha dalam mendesign kemasan label yang menarik maupun memberikan arahan terkait inovasi rasa. Dalam hal praktek tidak mengalami kesulitan karena sebelumnya mereka telah memiliki bekal dalam hal membuat kue ladrang.

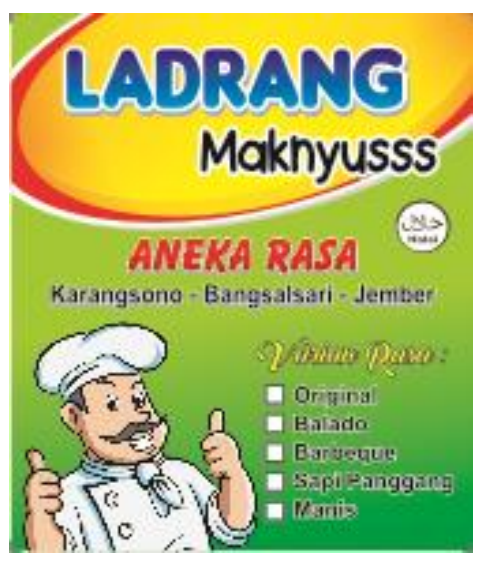

Gambar 5.5 Stiker kemasan (Hasil inovasi kemasan)

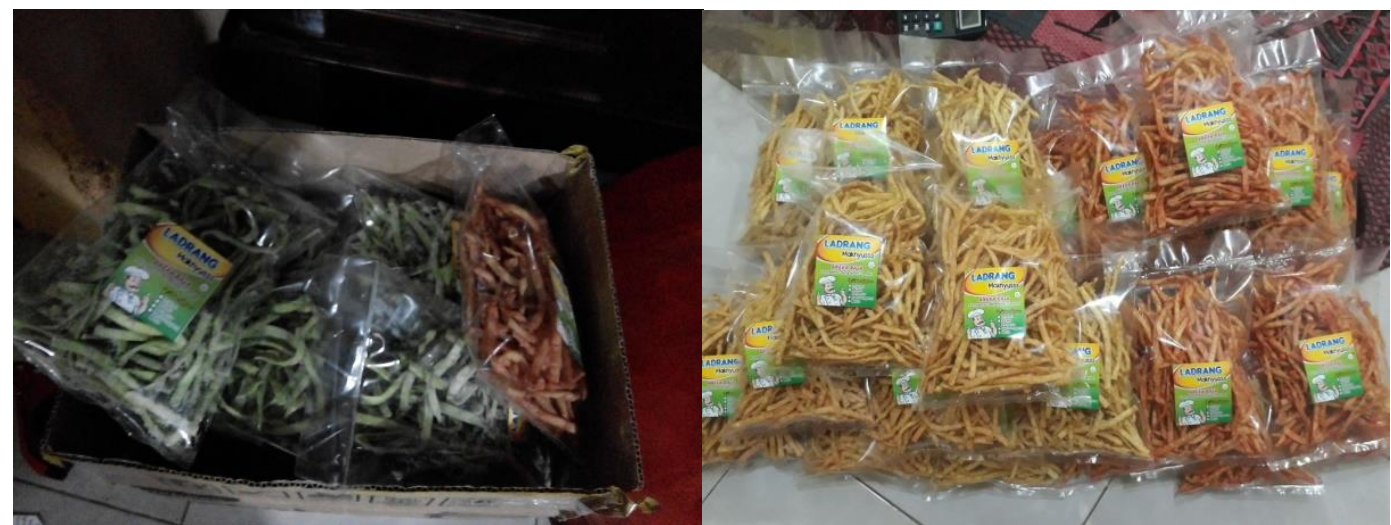

Gambar 5.6 Varians rasa kue ladrang (original, balado, sapi panggang, barbeque, dan manis)

\section{Produk Sebelum Adanya Inovasi}

Sebelum adanya inovasi produk, varians rasa hanya original dan balado, sedangkan kemasan produk hanya menggunakan plastik kecil dan tidak ada label kemasan. 


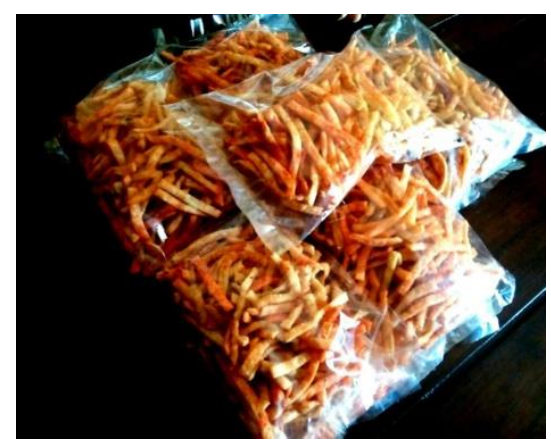

\section{Gambar 5.7 Produk Sebelum Adanya Inovasi}

\section{E. Produk Setelah Adanya Inovasi}

Setelah adanya inovasi produk, varians produk lebih banyak,dan kemasan produk lebih menarik dan higienis.

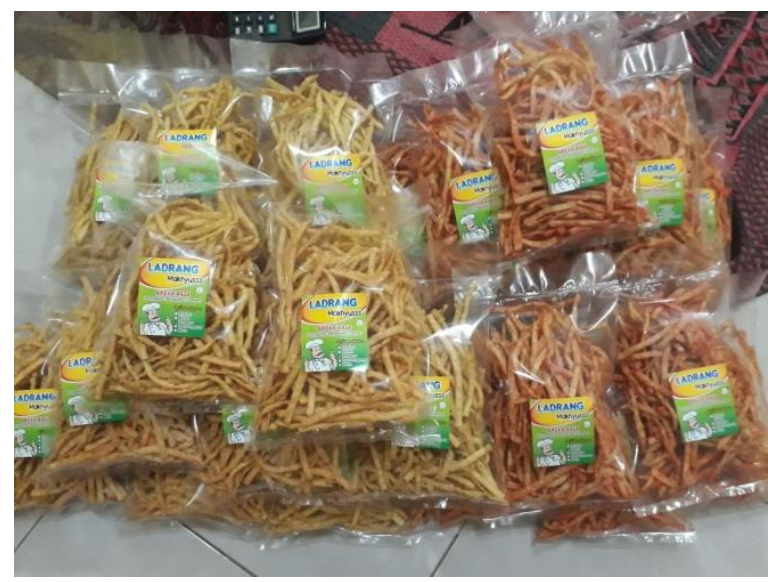

Gambar 5.8 Produk Setelah Adanya Inovasi

\section{F. Pendampingan Pemasaran dan Promosi}

Proses pemasaran di lakukan di toko-toko terdekat dan di daerah luar kota seperti lumajang. Proses pemasaran mendapat respon yang positif dari pemilik toko-toko disamping karena produk hasil kelompok usaha kue ladrang di desa karangsono yang enak, kue ladrang juga tergolong murah yaitu Rp 5.000 per bungkus.

Respon baik dari pemilik toko juga menyebutkan kue ladrang memiliki varians rasa yang banyak di gemari oleh masyarakat, selain itu kemasan juga sangat menarik dan higienis.

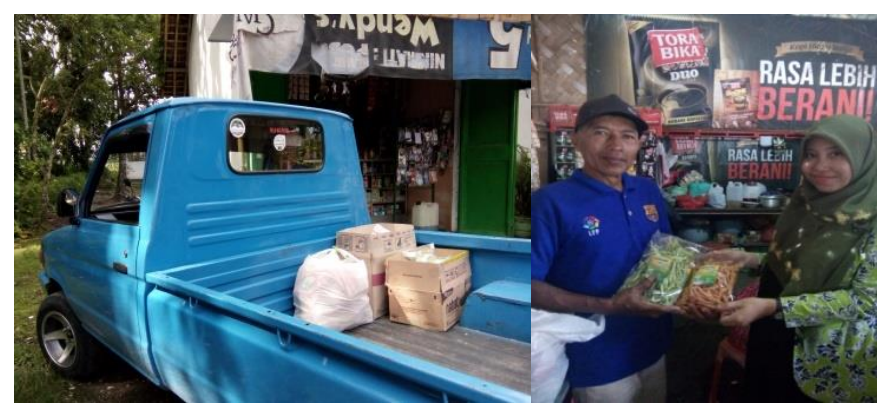

Gambar 5.9 Proses Pemasaran 
Pendampingan promosi dilakukan melalui media online facebook dan instagram, Terdapat respon positif oleh beberapa kalangan pengguna media sosial tentang kue ladrang hasil kelompok usaha kue ladrang di desa karangsono kecamatan bangsalsari kabupaten jember, disamping karena varians rasanya yang banyak, kemasan kue ladrang juga cukup menarik dan higienis.

\section{PENUTUP}

\section{A. Kesimpulan}

Program pengabdian masyarakat berjalan dengan baik dan lancar, pendampingan inovasi produk yang telah diusulkan berhasil membuat produk kue ladrang semakin menarik dan bervariatif. Kegiatan ini mendapat dukungan penuh dari kelompok usaha kue ladrang, karena berhasil memberikan gagasan yang baru dalam hal memberikan desaign kemasan, inovasi dan varians rasa baru.

\section{B. Saran}

Berdasarkan kegiatan yang telah dilakukan maka dapat diajukan beberapa saran sebagai berikut :

1. Adanya kegiatan sejenis hendaknya selalu diselenggarakan secara periodik sehinga dapat meningkatkan keterampilan dan kemandirian UMKM.

2. Minimnya biaya operasional kegiatan menjadikan inovasi terbatas.

3. Selain inovasi produk masih banyak kegiatan pengabdian masyarakat lain yang perlu dikembangkan seperti pelatihan managemen, pelatihan pencatatan akuntansi yang baik dan benar, dan sebagainya.

\section{DAFTAR PUSTAKA}

Akbar. 2015. Cara Membuat Kue Ladrang Bawang Enak Dan Renyah http://www.resepnasional.com/. Diakses 17 Februari 2018

BPS. 2016. UMKM. (online), (http://www.bps.go.id/index.php?news=730), diakses 18 Februari 2018

Kusumo, Agung Raharjo Wibowo. 2006. Analisis Faktor-Faktor Yang Mempengaruhi Inovasi Produk Untuk Meningkatkan Keunggulan Bersaing Dan Kinerja Pemasaran (Studi Pada Industri Batik Skala Besar Dan Sedang Di Kota Dan Kabupaten Pekalongan). Tesis. Universitas Diponegoro Semarang

Ria. 2015. Ide Bisnis Makanan Ringan Untuk Pemula https://www.cermati.com/. Di akses 17 Februari 2018 